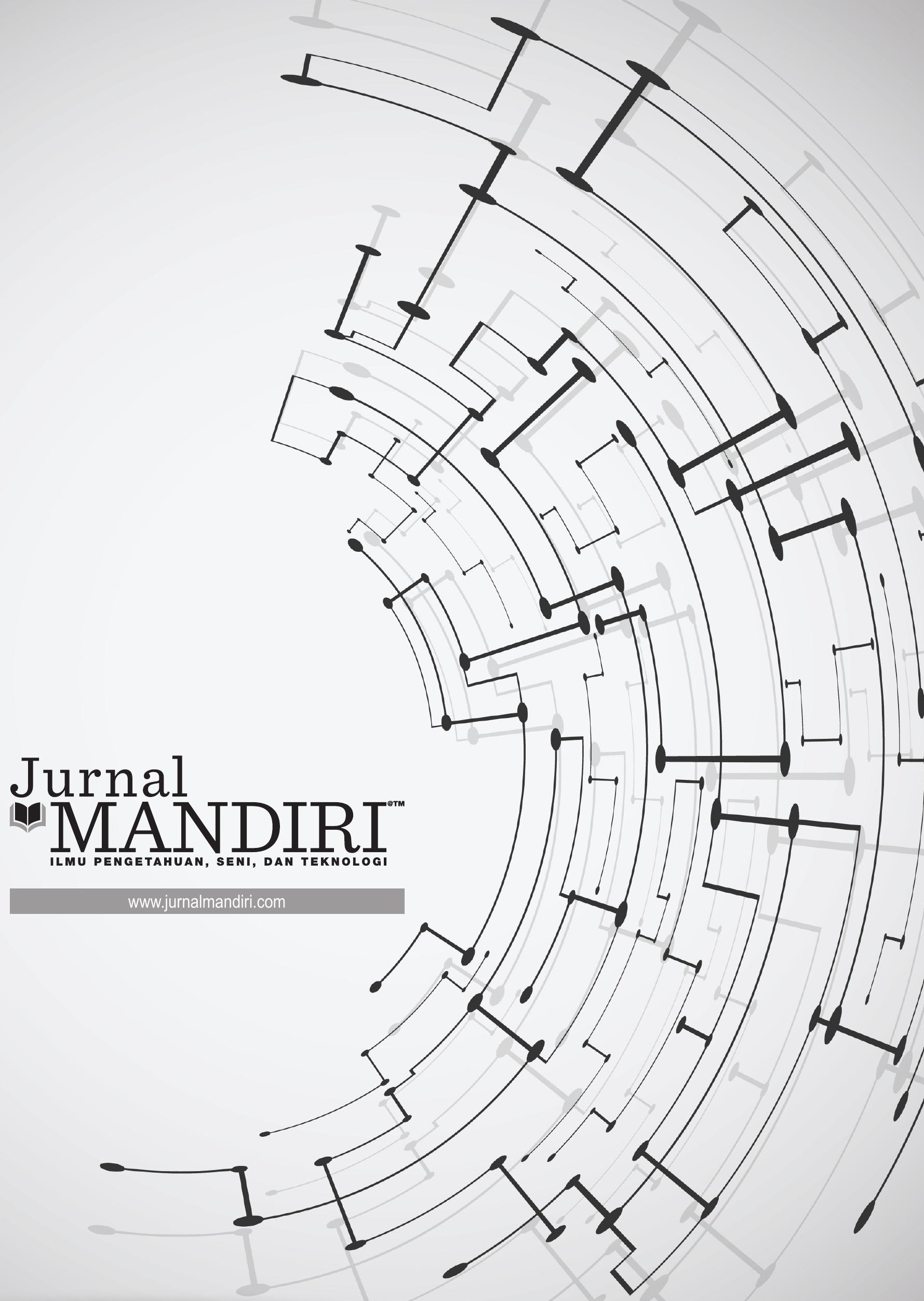


ISSN : 2580-3220, E-ISSN : 2580-4588

J. Mandiri., Vol. 3, No. 2, Desember 2019 (221 - 229)

(C)2018 Lembaga Kajian Demokrasi

dan Pemberdayaan Masyarakat (LKD-PM)

DOI : https://doi.org/10.33753/mandiri.v3i2.83

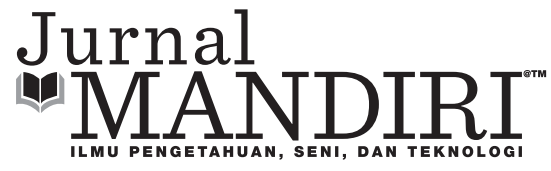

\title{
Kajian Valuasi Ekonomi Objek Wisata Sekar Langit Kabupaten Magelang Dengan Pendekatan Travel Cost Method
}

\author{
Fitrah Sari \\ Fakultas Ekonomi, Universitas Tidar \\ fitrahsari@untidar.ac.id \\ Rr. Retno Sugiharti \\ Fakultas Ekonomi, Universitas Tidar \\ retno.sugiharti@untidar.ac.id \\ Yulida Army \\ Fakultas Ekonomi, Universitas Tidar \\ yulidaarmy@untidar.ac.id
}

\begin{abstract}
Abstrak
Kabupaten Magelang berada di lereng gunung dengan topografi wilayah yang bervariasi memiliki potensi pariwisata lokasi yang sangat besar. Namun sayangnya objek-objek wisata di Kabupaten Magelang rata-rata belum dikelola dengan baik. Melalui penelitian ini, ingin mengkaji salah satu objek wisata di Kabupaten Magelang yaitu Air Terjun Sekar Langit. Dengan pertumbunhan jumlah kunjungan yang positif menunjukkan bahwa objek ini memiliki potensi untuk berkembang bila dikelola dengan baik. Menggunakan Travel Cost Method, penelitian ini bertujuan untuk menganalisis nilai ekonomi dari objek wisata Air Terjun Sekar Langit. Dengan harapan hasil penelitian ini dapat digunakan sebagai bahan pertimbangan Pemerintah Daerah dan Dinas terkait untuk mengelola namun di sisi lain kelestasrian alam objek wisata Sekar Langit tetap terjaga.
\end{abstract}

Kata Kunci : Pariwisata, Valuasi Ekonomi, Travel Cost Method

\begin{abstract}
Magelang Regency is on a mountainside with varied regional topography which has a very large tourism potential location. But unfortunately tourist attractions in Magelang regency on average have not been managed well. Through this research, we want to examine one of the tourist attractions in Magelang Regency, which is the Waterfall of Sekar Langit. With the growth in the number of positive visits shows that this object has the potential to develop if managed properly. Using the Travel Cost Method, this study aims to analyze the economic value of the Sekar Langit Waterfall attraction. With the hope that the results of this study can be used as consideration for the Regional Government and related agencies to manage, but on the other hand the natural preservation of the Sekar Langit tourist attraction is maintained.
\end{abstract}

Keywords : Tourism, economic valuation, Travel Cost Method

\section{PENDAHULUAN}

Industri pariwisata merupakan kegiatan yang terstruktur dan sistematis dan dipercaya memiliki multiplier effect yang nyata. Terbukanya sebuah kawasan pariwisata akan membuka kesempatan kerja bagi masyarakat sekitar, meningkatkan 
pendapatan masyarakat dengan dengan penjualan barang dan jasa antara lain: restoran, hotel, biro perjalanan, pramuwisata, barang-barang souvenir. Dari peningkatan pendapatan tentu akan meningkatkan kesejahteraan masyarakat di sekitar objek wisata dan secara agregat akan meningkatkan devisa negara.

Industri pariwisata Indonesia telah terbukti mampu bertahan menghadapi berkali-kali krisis ekonomi baik lokal maupun global. Hingga saat ini, rata-rata penerimaan dari industri pariwisata menduduki antara peringkat 3 atau 4 pada PDB nasional, berada setelah penerimaan dari sektor ekspor minyak dan gas bumi, industri tekstil, dan industri pakaian jadi (Gewati, 2019). Selain itu industri pariwisata juga menjadi andalan penerimaan devisa negara sehingga target kunjungan wisatawan mancanegara ke Indonesia pun terus digenjot oleh Pemerintah, pada 2019 target kunjungan wisatawan mancanegara sebesar 20 juta pengunjung dengan target penerimaan devisa total sebesar 270 juta (Gewati, 2019). Maka tidak dapat dipungkiri bahwa sumbangan devisa dari industri Pariwisata memegang peran yang sangat penting dalam perekonomian, terlebih pendapatan dari turis mancanegara (Juliprijanto, 2014).

Berada di dataran tinggi, diapit oleh tujuh gunung (Gunung Merapi, Gunung Merbabu, Gunung Sumbing, Gunung Sindoro, Gunung Prau, Gunung Andong, dan Gunung Telomoyo) dengan keindahan alam yang luar biasa indah, menjadi daya tarik utama pariwisata Kabupaten Magelang. Kondisi geografis tersebut mejadikan Kabupaten Magelang memiliki hawa yang sejuk dan keanekaragaman objek wisata yang sangat beragam. Berbagai macam kesenian, kebudayaan, kerajinan dan cinderamata, hotel, rumah makan, berbagai wisata kuliner dari aneka makanan khas Kabupaten Magelang serta didukung keberadaan wisata candi yang beragam, yang menarik kunjungan para wisatawan baik nusantara maupun mancanegara.

Potensi pariwisata yang dimiliki oleh Kabupaten Magelang disadari penuh oleh Pemerintah Kabupaten Magelang. Pemerintah Kabupaten Magelang melalui Dinas Pariwisata Kepemudaan dan Olahraga Kabupaten Magelang terus berusaha menggenjot pertumbuhan pariwisata di Kabupaten Magelang. Langkah nyata pemerintah daerah adalah dengan penetapan Perda Kabupaten Magelang Nomor 4 Tahun 2015 tentang Rencana Induk Pembangunan Kepariwisataan Kabupaten Magelang Tahun 2014-2034. Dengan mengusung visi "Terwujudnya Kabupaten Magelang sebagai Kabupaten Wisata Yang Berdaya Saing dan Berwawasan Budaya" beberapa langkah strategis telah dirumuskan untuk mendukung terwujudnya visi tersebut.

Hingga saat ini primadona pariwisata Kabupaten Magelang masih dipegang oleh Candi Borobudur. Hingga tahun 2019, lebih dari 85 persen pendapatan sektor pariwisata merupakan sumbangan dari Candi Borobudur dengan ratarata kunjungan 3.161.321 wisatawan domestik dan 209.665 wisatawan mancanegara per tahun. Hal ini menjadikan Candi Borobudur menjadi objek pariwisata yang penyumbang pendapatan terbesar tidak hanya di Kabupaten Magelang namun juga di Provinsi Jawa Tengah. Bahkan Candi Borobudur ditetapkan sebagai salah satu dari empat destinasi yang menjadi pariwisata prioritas bersama dengan tiga wisata lain yaitu Mandalika, Danau Toba, Labuan Bajo. Empat objek wisata ini menjadi konsentrasi utama pembangunan infrastruktur pendukung.

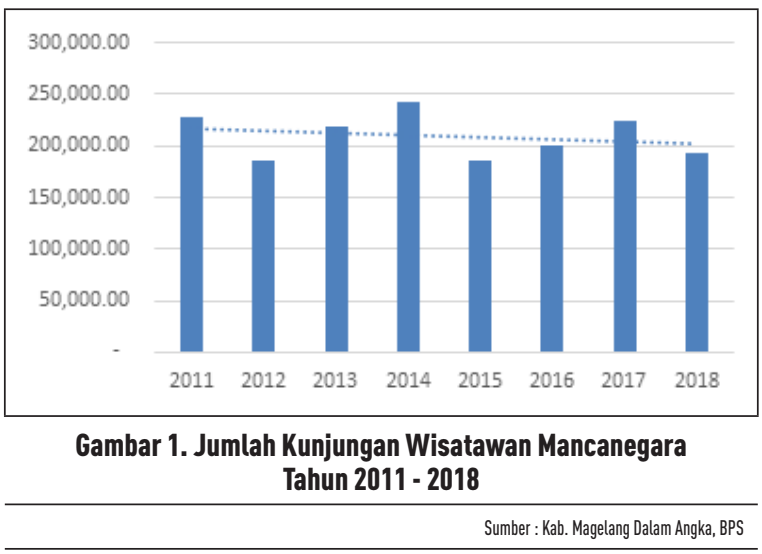

Namun demikian, data kunjungan wisatawan pada tahun 2011-2018, khususnya kunjungan wisatawan mancanegara di Candi Borobudur menunjukkan tren menurun.

Meskipun penurunannya tidak signifikan (rata-rata penurunan sebesar 4 persen), namun 
hal ini merupakan pertanda bahwa tidak selamanya pendapatan pariwisata Kabupaten Magelang dapat terus-menerus bergantung pada objek Candi Borobudur. Kabupaten Magelang memiliki banyak potensi wisata yang dapat dikembangkan khususnya objek wisata alam. Total tercatat ada 21 objek wisata wisata alam baik yang sudah dikembangkan maupun yang belum di Kabupaten Magelang, misalnya Arung Jeram, wisata naik gunung, air terjun, wisata desa wisata dan lain sebagainya.

Salah satu potensi objek wisata alam yang cukup menjanjikan untuk dikembangkan adalah Objek Wisata Air Terjun Sekar Langit. Daerah tujuan wisata (DTW) yang berada di Kecamatan Telogorejo Kabupaten Magelang mempunyai keunikan tersendiri yaitu cerita rakyat atau Legenda tentang Joko Tarub dan 7 bidadari yang melekat erat pada DTW ini. Namun sayangnya keunikan yang dimiliki objek wisata ini tidak mampu meningkatkan jumlah kunjungan wisatawan untuk datang ke objek wisata Sekar Langit. Grafik di bawah ini menunjukkan jumlah kunjungan wisatawan ke objek wisata Air Terjun Sekar Langit:

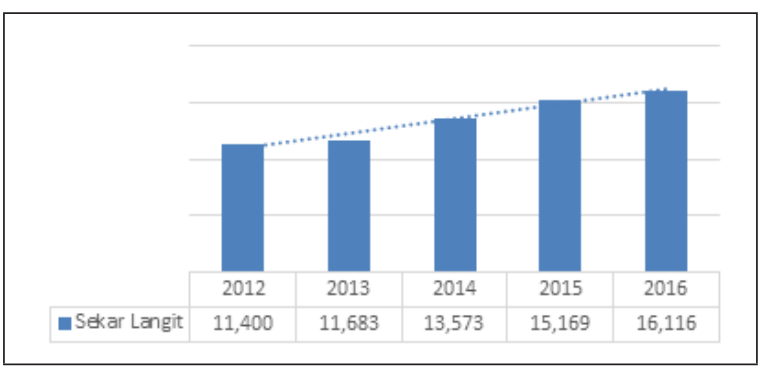

Gambar 2. Jumlah Kunjungan Wisatawan Ke Objek Wisata Air Terjun Sekar Langit

Sumber : Kab. Magelang Dalam Angka, BPS

Kunjungan wisatawan ke DTW Air Terjun Sekar Langit hanya menyumbang 0.34 persen dari total kunjungan wisatawan ke Kabupaten Magelang. Walau demikian, keberadaan DTW Air Terjun Sekar Langit sangat penting bagi Kabupaten Magelang khususnya bagi warga sekitar DTW Air Terjun Sekar Langit. Keberadaan DTW Air Terjun Sekar Langit selama ini telah menjadi sektor penggerak perekonomian dalam bentuk penciptaan lapangan pekerjaan dan sumbangan ekonomi dari tiket masuk yang dibayarkan oleh pengunjung. Dengan rata-rata pertumbuhan jumlah pengunjung DTW Air Terjun Sekar Langit sebesar 8.2 persen, pada dasarnya DTW Air Terjun Sekar Langit memiliki potensi yang cukup besar. Oleh karena itu, agar dapat mendatangkan keuntungan ekonomi dan nilai tambah bagi masyarakat sekitar pada khususnya dan sumbangan pendapatan bagi wilayah Kabupaten Magelang pada umjumnya, maka keberadaan wisata ini harus ditingkatkan dan dikembangkan.

Penilaian, pengembangan dan perencanaan wilayah ekonomi khususnya untuk objek pariwisata perlu dilakukan dengan cermat. Memanfaatkan sumber daya alam dan lingkungan sebagai daerah wisata adalah salah satu upaya untuk mengeksplorasi dan menambah nilai tambah bagi sumber daya alam dan lingkungan itu sendiri (Susilowati, Syah, Suharno, \& Aminata, 2018). Namun, sebelum melakukan perencanaan dan pengembangan atas suatu objek wisata, perlu dilakukan kajian terkait nilai ekonomis dari objek wisata tersebut. Nilai ekonomis yang dimaksud adalah jasa lingkungan, yaitu keindahan alam yang diberikan oleh suatu tempat atau alam yang kemudian dimanfaatkan sebagai objek wisata. Salah satu teknik valuasi ekonomi atas nilai ekonomis objek wisata dapat dilakukan dengan menggunakan Metode Biaya Perjalanan Travel CostMethod(TCM). Pendekatan inimenggunakan sudut pandang total biaya perjalanan yang dikeluarkan pengunjung untuk datang ke objek wisata. Travel Cost Method menggunakan asumsi bahwa total biaya perjalanan yang bersedia dibayar oleh para wisatawan (willingness to pay) dan waktu yang dikorbankan para wisatawan untuk menuju objek wisata dihitung sebagai nilai atas lingkungan. Dalam suatu perjalanan, orang harus membayar biaya finansial dan biaya waktu di mana biaya waktu tergantung pada biaya kesempatan. Besaran nilai ini akan menghasilkan nilai atau value atas lingkungan pada objek wisata yang dinilai.

Metode TCM telah terbukti merupakan metode yang handal dalam memprediksi nilai lingkungan atas objek wisata. Beberapa penelitian yang menggunakan metode TCM antara lain: (1) Aryanto dan Mardjuka (2005); mengambil objek 
penelitian di DTW Ujung Genteng, Aryanto dan Mardjuka (2005) melakukan penelitian dengan tujuan untuk mempelajari fenomena yang berkaitan dengan berbagai profil dan aktifitas wisata di kawasan Ujung Genteng, Kabupaten Sukabumi dengan fokus pembahasan pada pengelolaan sumberdaya alam yang tepat bagi ekowisata pesisir dengan mempertimbangkan valuasi ekonomi sebagai dasar perhitungan. (2) Penelitian oleh Pramudhito (2010) di mana metode TCM digunakan pada Wisata Alam Air Terjun Jumog Kabupaten Karanganyar. (3) Subardin dan M. Komri Yusuf (2011) juga menggunakan metode TCM untuk menganalisis kesediaan seseorang untuk membayar sejumlah uang untuk suatu komoditi yang diperdagangkan. Nilai ini kemudian digunakan untuk memperoleh nilai utilitas maksimum pada DTW Taman Wisata Alam Punti Kayu Palembang. Dalam hal ini metode Travel Cost diterapkan dengan asumsi bahwa biaya yang dikeluarkan untuk membayar tarif masuk tidak sebanding dengan manfaat atau kepuasan yang diterima oleh pengunjung.

Karena kemudahan dan kehandalan metode TCM, beberapa penelitian terdahulu di beberapa negara juga mengaplikasikan metode TCM. Penelitian yang dilakukan oleh Cho, Bowker, English, Roberts, \& Kim (2014), menggunakan TCM sebagai salah satu metode untuk menganalisis penurunan yang cukup signifikan pada wisata rekreasi hutan. Penelitian tersebut bertujuan untuk mengevaluasi dampak biaya perjalanan pada permintaan rekreasi dan partisipasi pengunjung dalam berbagai jenis kegiatan rekreasi pada objek wisata hutan. Hasil dari penelitian ini menyimpulkan bahwa peningkatan dana yang dialokasikan oleh wisatawan untuk meningkatkan kegiatan rekreasi berbasis nontrail dan backpacking merupakan salah satu solusi yang dapat dilakukan untuk mengatasi hilangnya surplus konsumen karena penurunan kunjungan wisatawan khususnya pada objek wisata hutan. Penelitian lain dilakukan oleh Prayaga (2017). Prayaga (2017) melakukan penelitian untuk menganalisis nilai ekonomi dari objek wisata pantai di Australia. Didorong oleh fenomena bahwa masih sangat sedikit penelitian yang mem- perkirakan nilai penggunaan rekreasi dari pantai terutama bagi pengunjung yang tinggal dekat kurang dari $5 \mathrm{~km}$ dari pantai atau penduduk setempat. Hal ini terjadi karena penduduk yang tinggal dekat dengan lokasi wisata memiliki pola kunjungan yang berbeda dan biaya perjalanan yang rendah dan malah nol. Mengambil objek di wilayah Pantai Capricorn di Great Barrier Reef di Queensland, penelitian ini menggunakan model campuran untuk memperkirakan nilai ekonomi pantai bagi penduduk setempat. Hasil menunjukkan bahwa ada perbedaan nilai untuk penggunaan pantai di antara penduduk setempat tergantung pada pola kunjungan mereka. Informasi ini sangat penting ketika mengevaluasi opsi kebijakan yang terkait dengan perlindungan dan pengelolaan pantai.

Dari beberapa penelitian terdahulu, disimpulkan bahwa TCM lebih disukai daripada teknik valuasi lain. Hal ini dilandasi TCM menggunakan teori permintaan untuk memperkirakan dan menjelaskan nilai kegiatan rekreasi berdasarkan pada asumsi sederhana bahwa, permintaan untuk rekreasi berbanding terbalik dengan biaya perjalanan (Armbrecht, 2014; Grilli, Landgraf, Curtis, \& Hynes, 2018; Jala \& Nandagiri, 2015; Mayer \& Woltering, 2018; Zaman, Moemen, \& Islam, 2016; Zambrano-Monserrate, Silva-Zambrano, \& Ruano, 2018) Maka dari itu, penelitian ini bertujuan untuk mengestimasi potensi nilai ekonomi dari Objek Wisata Air Terjun Sekar Langit menggunakan pendekatan Travel Cost Method serta mengidentifikasi faktor-faktor yang berpengaruh terhadap tingkat kunjungan wisatawan ke DTW Air Terjun Sekar Langit.

Untuk menuju pembangunan wisata berkelanjutan, pemanfaatan potensi Objek Wisata Air Terjun Sekar Langit harus dilakukan dengan perencanaan strategis dan strategi pengembangan yang tepat. Penilaian manfaat Objek Wisata Air Terjun Sekar Langit merupakan salah satu bahan masukan yang digunakan untuk mengukur besaran manfaat atas DTW Air Terjun Sekar Langit untuk mencapai perencanaan dan pengembangan Objek Wisata Air Terjun Sekar Langit. Dalam hal ini pengambilan keputusan akan lebih mudah jika manfaat dari penggunaan potensi sumberdaya 
alam tersebut dapat dinyatakan dalam bentuk nilai kuantitatif terutama dalam nilai rupiah. Maka dari itu batasan masalah dalam penelitian ini adalah penggunaan valuasi ekonomi sumberdaya alam dan lingkungan yang akan menggambarkan nilai atas jasa lingkungan DTW Air Terjun Sekar Langit dengan metode Travel Cost Method.

\section{METODE}

Penelitian ini dilakukan di DTW Air Terjun Sekar Langit dalam periode Juli-Oktober 2019. Kegiatan pengumpulan data dilakukan pada hari Sabtu dan Minggu dengan dasar bahwa tingkat kehadiran pengunjung lebih ramai pada hari libur dibandingkan dengan hari kerja. Sedangkan populasi dalam penelitian ini adalah seluruh pengunjung di objek wisata Sekar Langit, seluruh pengunjung dapat menjadi objek penelitian. Oleh karena itu metode sampling yang digunakan dalam penelitian ini adalah nonprobability sampling dengan teknik sampling menggunakan teknik sampling aksidental, yakni sampel yang diambil dari siapa saja yang kebetulan ada saat pengambilan data berlangsung. Pemilihan teknik sampling ini karena metode ini mudah dan cepat untuk dilakukan. Untuk jumlah sampel yang diambil menggunakan Rumus Cochran (Sudarmanto, 2011). Rumus Cochran dianggap sesuai dalam situasi dengan populasi besar. Dengan menggunakan asumsi 5 dari 100 orang penduduk terdekat yang tinggal di sekitar DTW Air Terjun Sekar Langit pernah berkunjung ke Air Terjun Sekar Langit (sebagai besaran nilai proporsi dari karakteristik tertentu), tingkat kepercayaan yang digunakan digunakan 0,95 sehingga nilai $t=1,96$, taraf kekeliruan yang digunakan sebesar 0,05 maka diperoleh jumlah sampel minimal sebesar 72, 99 untuk memudahkan maka jumlah sample yang diambil sebesar 75 responden.

Variabel yang digunakan dalam penelitian ini adalah variabel dependen yaitu Frekuensi Kunjungan (Y) adalah frekuensi kunjungan wisatawan ke DTW Air Terjun Sekar Langit. Variabel ini diukur dengan satuan jumlah kedatangan per pengunjung. Sedangkan variabel Independen yaitu pertama, Jarak Tempat Tinggal $\left(\mathrm{X}_{1}\right)$ adalah
Panjang jarak dari tempat asal wisatawan ke lokasi Air Terjun Sekar Langit, variabel ini diukur dengan satuan kilometer. Kedua, Pendapatan $\left(\mathrm{X}_{2}\right)$ adalah penghasilan rata-rata per bulan dari wisatawan. Nilai ini berasal dari penghasilan keseluruhan wisatawan, sedangkan bagi responden yang belum bekerja, pendapatan adalah uang saku yang diperoleh setiap bulan. Variabel ini diukur dengan satuan rupiah. Ketiga, Biaya Perjalanan (travel cost) $\left(\mathrm{X}_{3}\right)$ adalah total biaya perjalanan yang dikeluarkan oleh wisatawan untuk menuju ke Objek Wisata Air Terjun Sekar Langit. Total biaya ini meliputi: Biaya transportasi, Biaya konsumsi, Biaya Kebersihan, Biaya Penginapan, Biaya Dokumentasi, Biaya parkir, dan Biaya Kamar Mandi. Variabel ini diukur dengan satuan rupiah.

Analisis data yang digunakan dalam penelitian ini adalah analisis Regresi Linear Berganda. Analisis ini digunakan untuk mengetahui seberapa besar pengaruh variabel bebas yaitu jarak tempat tinggal, pendapatan, dan biaya perjalanan terhadap variabel terikat yaitu frekuensi kunjungan wisatawan Objek Wisata Air Terjun Sekar Langit. Model Travel Cost yang digunakan adalah sebagai berikut:

Frekuensi Kunjungan $=\mathrm{f}$ (Jarak Tempat Tinggal, Pendapatan, Total Travel Cost)

Frekuensi Kunjungan Wisatawan $=\alpha+\beta_{1}$ Jarak Tempat Tinggal $+\beta_{2}$ Pendapatan $+\beta_{3}$ Total Travel Cost $+\mathrm{e}$

Di mana :

$\mathrm{Y}=$ =Frekuensi kunjungan wisatawan

a = Konstanta

$\beta_{1}, \beta_{2}, \beta_{3}=$ Koefisien regresi

$\mathrm{X}_{1} \quad=$ Jarak tempat tinggal

$\mathrm{X}_{2} \quad=$ Pendapatan

$\mathrm{X}_{3} \quad=$ Total Travel Cost

$\mathrm{e}=$ error

Travel Cost Method ini selanjutnya data akan dianalisis secara kuantitatif dengan menggunakan alat analisis Eviews 10 dengan Metode OLS (Ordinary Least Squares).

\section{HASIL dan PEMBAHASAN \\ Hasil}

Dari survei yang telah dilakukan diperoleh total responden sejumlah 75 responden dengan komposisi 40 persen responden wanita dan 60 
persen responden laki-laki. Karakteristik responden ditampilkan sebagai berikut:

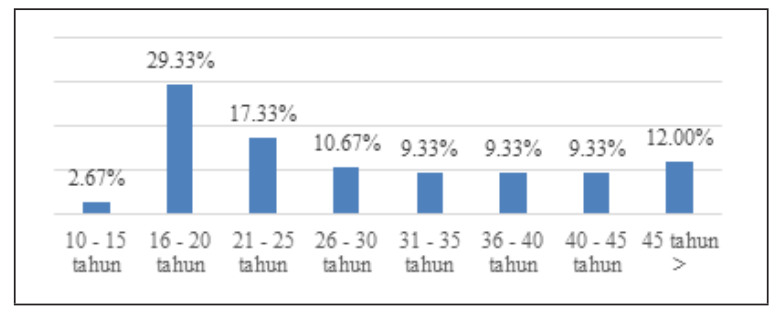

Gambar 3. Sebaran Usia Responden

Dari Gambar 3, pengunjung objek wisata Air Terjun Sekar Langit Kabupaten Magelang didominasi usia muda yaitu dari usia 10 tahun hingga 30 tahun sebesar 60 persen dari total keseluruhan pengunjung. Tidak dapat dipungkiri bahwa untuk objek wisata alam membutuhkan kekuatan fisik yang mumpuni agar dapat sampai ke lokasi. Meskipun jarak dari pintu masuk ke air terjun tidak jauh, tetapi medan jalan cukup membahayakan. Oleh karena itu pengunjung objek wisata alam cenderung didominasi oleh usia muda. Pada penelitian ini tidak membatasi usia pengunjung yang menjadi responden. Untuk responden yang berusia di bawah 15 tahun atau diatas 15 tahun tetapi belum bekerja, maka variabel pendapatan dihitung dari uang saku yang diberikan orang tua responden. Meskipun belum mempunyai pendapatan sendiri, responden yang berusia di bawah 15 tahun atau diatas 15 tahun tetapi belum bekerja tetap mengorbankan sejumlah uang yang dimiliki untuk datang ke DTW Air Terjun Sekar Langit.

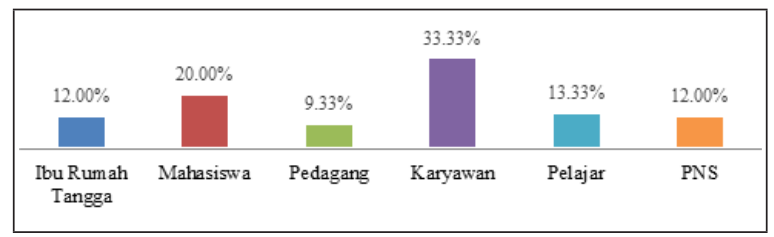

Gambar 4. Karakteristik Pengunjung Berdasarkan Pekerjaan

Pengunjung Objek Wisata Sekar Langit didominasi oleh pengunjung dengan pekerjaan sebagai karyawan, mahasiswa dan pelajar.

Dari sisi pengunjung, 100 persen pengunjung yang datang ke objek wisata Sekar Langin menggunakan kendaraan pribadi baik roda dua maupun roda empat, hal ini memang karena belum ada transportasi umum yang menuju atau melewati lokasi wisata ini. Dalam kunjungan tersebut, yang berkunjung satu kali sebesar 46,7 persen, dua kali sebesar 23,4 persen, tiga kali sebesar 23,3 persen dan lebih dari empat kali sebesar 6,8 persen. Sebesar 50 persen responden mengatakan bahwa Objek Wisata Air Terjun Sekar Langit Kabupaten Magelang indah. Pada umumnya, responden mendapat informasi mengenai objek wisata tersebut dari teman atau keluarga (90 persen). Adapun tujuan mengunjungi tempat ini sebagian besar karena ingin berwisata alam yaitu sebesar 90 persen. Alasan mengunjungi tempat ini karena Air Terjun Sekar Langit menarik (40 persen). Sebesar 75 persen responden mengatakan bahwa kunjungan mereka ke Air Terjun Sekar Langit merupakan tujuan utama mereka tanpa adanya tujuan kunjungan ke wiata lain. Responden menyarankan bahwa sangat perlu dilakukannya penambahan fasilitas di Objek Wisata Air Terjun Sekar Langit Kabupaten Magelang

Estimasi Travel Cost Method dilakukan menggunakan model Regresi. Model ini dipiliih karena tujuan dari TCM adalah mengetahui kuat lemahnya keterikatan hubungan antara pengorbanan besaran biaya yang dikeluarkan oleh wisatawan dengan frekuensi kunjungan wisatawan yang bersangkutan ke DTW Air Terjun Sekar Langit. Koefisien parameter dari biaya yang dikeluarkan dapat dibaca sebagai elastisitas jumlah kunjungan wisatawan.

Langkah awal sebelum melakukan estimasi regresi pada fungsi frekuensi kunjungan responden, terlebih dahulu dilakukan deteksi atas pelanggaran asumsi klasik pada model regresi. Apabila terjadi pelanggaran atas asumsi klasik maka model menjadi bias dan tidak dapat digunakan untuk memprediksi koefisien dalam model yang dibangun.

Maka dari hasil perhitungan, Uji Normalitas menunjukkan nilai uji Jarque-Bera 91.79626 dengan probabilitas 0.000 yang menunjukkan terjadinya pelanggaran terhadap asumsi klasik, yang diduga terjadi karena keberadaaan outlier dalam data. Oleh karena itu estimasi regresi dilakukan dengan metode Robust Least Square (Rahman \& Widodo, 2018). 


\begin{tabular}{|c|c|c|c|c|}
\hline \multicolumn{5}{|c|}{$\begin{array}{l}\text { Tabel 1. Hasil Regresi dengan White heteroskedasticity } \\
\text { consistent standard errors \& covariance }\end{array}$} \\
\hline VARIABEL & KOEFISIEN & STD. ERROR & Z-STATISTIC & PROB. \\
\hline Jarak & -0.382285 & 0.114812 & 0.114812 & $0.0009^{* * *}$ \\
\hline Pendapatan & -0.065972 & 0.067839 & 0.067839 & 0.3308 \\
\hline Total Cost & -0.024654 & 0.058879 & 0.058879 & 0.6754 \\
\hline c & 1.433643 & 0.865811 & 0.865811 & $0.0978^{*}$ \\
\hline \multicolumn{5}{|c|}{${ }^{* * *}$ Signifikan 10\%, ${ }^{* *}$ Signifikan $5 \%,{ }^{*}$ signifikan $1 \%$} \\
\hline
\end{tabular}

Selain hasil yang ditampilkan pada Tabel 1. dari hasil regresi diperoleh nilai R-squared 0.103187, yang berarti bahwa variabel Frekuensi kunjungan wisatawan $(\mathrm{Y})$ dapat dijelaskan oleh variabel jarak tempat tinggal $\left(\mathrm{X}_{1}\right)$, pendapatan $\left(\mathrm{X}_{2}\right)$, biaya perjalanan $\left(\mathrm{X}_{3}\right)$, sebesar 10.3 persen dan sisanya sebesar 89.68 persen dijelaskan oleh variabel-variabel lain diluar model regresi tersebut.

Uji Hipotesis dilakukan per masing-masing variabel dengan pembahasan hasil sbb: (1) Hasil estimasi regresi untuk variabel Jarak Tempat Tinggal $\left(\mathrm{X}_{1}\right)$ yaitu diperoleh probability sebesar 0.0009 , nilai lebih kecil dari nilai taraf signifikansi $\alpha=5 \%$ maka Hipotesis nol $\left(\mathrm{H}_{\mathrm{o}}\right)$ diterima dan Hipotesis alternative $\left(\mathrm{H}_{\mathrm{a}}\right)$ dapat ditolak, sehingga dapat diartikan bahwa jarak tempat tinggal $\left(\mathrm{X}_{1}\right)$, mempunyai pengaruh negatif signifikan terhadap variabel Frekuensi kunjungan wisatawan (Y). (2) Hasil estimasi regresi untuk variabel Pendapatan diperoleh probability sebesar 0.3308 lebih besar dari nilai taraf signifikansi $\alpha=5 \%$ maka Hipotesis nol $\left(\mathrm{H}_{\mathrm{o}}\right)$ diterima dan Hipotesis alternative $\left(\mathrm{H}_{\mathrm{a}}\right)$ ditolak, sehingga dapat diartikan bahwa variabel pendapatan $\left(\mathrm{X}_{2}\right)$ mempunyai pengaruh negatif tidak signifikan terhadap variabel banyaknya kunjungan wisatawan (Y). (3) Variabel Total Biaya Perjalanan/Total Cost $\left(\mathrm{X}_{3}\right)$, diperoleh nilai probabilitas 0.6754 lebih besar dari nilai taraf signifikansi $\alpha=5 \%$ maka Hipotesis nol $\left(\mathrm{H}_{\mathrm{o}}\right)$ diterima dan Hipotesis alternative $\left(\mathrm{H}_{\mathrm{a}}\right)$ dapat ditolak, sehingga dapat diartikan bahwa variabel biaya perjalanan $\left(\mathrm{X}_{3}\right)$ mempunyai pengaruh negatif tidak signifikan terhadap variabel banyaknya kunjungan wisatawan $(\mathrm{Y})$.

Dari hasil estimasi pada tabel 4.1 dapat dituliskan persamaan akhir sebagai berikut:

Frekuensi Kunjungan Wist $=1.433643$ -0.382285 Jarak -0.065972 Pendapatan -0.024654
Total Cost $+\varepsilon$

Dari hasil estimasi tersebut dapat di interprestasikan bahwa apabila nilai variabel jarak tempat tinggal meningkat sebesar satu satuan maka akan menurunkan banyaknya kunjungan wisatawan sebesar 0.382285 dalam setiap satuannya, ceteris paribus.

\section{Pembahasan}

Dari koefisien determinasi menunjukkan nilai yang sangat kecil, dan dari hasil regresi diketahui bahwa pengunjung yang datang ke objek wisata air terjun Sekar Langit hanya terpengaruh oleh Jarak, namun tidak dipengaruhi oleh variabel Pendapatan dan Total Biaya, dengan kata lain kunjungan wisatawan ke objek wisata air terjun Sekar Langit tidak dipengaruhi oleh sisi ekonomi dan cakupan kunjungan DTW Air Terjun Sekar Langit masih dalam lingkup lokal. Hal ini juga secara tidak langsung menyiratkan bahwa semakin tinggi penghasilan pengunjung maka pengunjung akan lebih memilih tempat wisata lain yang memiliki tingkat prestise yang lebih tinggi. Dalam hal ini, metode Travel Cost tidak terbukti dalam kasus DTW Air Terjun Sekar Langit.

Meskipun sulit bukan berarti tidak mungkin untuk menarik wisatawan mancanegara untuk datang ke DTW Sekar Langit. Yang perlu dilakukan adalah melakukan kajian mendalam terkait beberapa aspek antara lain (Hadji, Wahyudi, \& Budi, 2017): a) Aspek Kelembagaan; meliputi pemanfaatan dan peningkatan kapasitas Lembaga yang menaungi pengelolaan DTW Sekar Langit. Lembaga ini akan berperan sebagai mekanisme yang akan mengatur berbagai kepentingan. Aspek ini sangat penting terlebih dari wawancara dengan pengelola DTW Air Terjun Sekar Langit, ada masalah internal dari sisi kelembagaan yang menghambat pengembangan DTW Air Terjun Sekar Langit. Mendatang, aspek kelembagaan ini sebaiknya menjadi prioritas utama untuk diselesaikan terlebih dahulu sebelum merambah pada aspek-aspek yang lain. b) Aspek Perencanaan Pembangunan; aspek perencanaan pembangunan akan melingkupi sistem perencanaan kawasan, tata ruang wilayah objek wisata, standarisasi, 
identifikasi potensi, koordinasi lintas sektoral, pendanaan, dan sistem informasi obyek wisata alam. c) Aspek Sarana dan Prasarana; aspek sarana dan prasarana memiliki dua sisi kepentingan, yaitu pertama, sebagai alat untutk memenuhi kebutuhan pariwisata alam, kedua sebagai pengendalian dalam rangka memelihara keseimbangan lingkungan, pembangunan sarana dan prasarana dapat meningkatkan daya dukung sehingga upaya pemanfaatan dapat dilakukan secara optimal. d) Aspek Pengelolaan; aspek pengelolaan erat kaitannya dengan aspek kelembagaan, namun pada aspek ini akan berfokus pada pengembangan profesionalisme dan pola pengelolaan obyek wisata alam yang siap mendukung kegiatan pariwisata alam dan mampu memanfaatkan potensi obyek wisata alam secara lestari serta mengatur pemanfaatan obyek wisata alam untuk tujuan pariwisata yang bersifat komersial kepada pihak ketiga. Pada aspek pengelolaan terkandung di dalamnya adalah aspek peran serta masyarakat, maka dalam aspek pengelolaan perlu dilihat dari 3 (tiga) sisi pengelola yaitu: pemerintah daerah, aspek masyarakat, dan pihak swasta di dalam suatu sistem tata ruang wilayah. e) Aspek Pemasaran; di awal aspek pemasaran akan berfokus pada mengenalkan secara lebih luas DTW Air Terjun Sekar Langit, tentu dengan memanfaatkan teknologi dan menjalin bekerja sama dengan berbagai pihak baik dalam negeri maupun luar negeri. Dalam aspek pemasaran, muatan budaya pada DTW Air TErjun Sekar Langit dapat menjadi sorotan utama. Salah satu cara yaitu menyelenggarakan Pagelaran atau event budaya untuk lebih mengenalkan kepada masyarakat luas tentang keberadaan DTW Air Terjun Sekar Langit. Selain itu juga diperlukan pula pengembangan dan penganekaragaman daya tarik wisata seperti pembuatan waterboom atau waterpark, agar pengunjung yang telah berkunjung bersedia untuk datang kembali ke objek wisata Air Terjun Sekar Langit.

\section{SIMPULAN}

Kabupaten Magelang memiliki banyak sekali potensi keindahan alam yang belum banyak di- eksplorasi, sehingga menjadikan beberapa daya tarik wisata yang baru ditemukan menjadi hal baru dan memiliki ketertarikan tersendiri terhadap wisatawan. Namun pada objek DTW Air Terjun Sekar Langit, nilai ekonomis dari objek wisata tersebut belum tereksploitasi dengan optimal. Kedepan, perlu dilakukan pengembangan dengan perencanaan yang baik dan matang akan DTW Air Terjun Sekar Langit dapat menarik lebih banyak wisatawan untuk berkunjung.

Pengembangan dapat dilakukan dengan tahapan: (1) Pengembangan struktur perekonomian daerah yang berbasis masyarakat melalui peningkatan kemampuan pelaku usaha wisata, perlindungan pengunjung wisata, (2). Pengembangan diversifikasi produk, peningkatan kinerja kelembagaan, dan sarana prasarana pendukung obyek wisata, (3). Pengembangan pariwisata yang bertumpu pada pemberdayaan masyarakat serta kemitraan usaha dalam rangka memperluas lapangan kerja dan kesempatan berusaha dengan tetap memelihara nilai-nilai budaya bangsa dan agama serta kelestarian lingkungan. (4) Memberikan kenyamanan wisatawan berkunjung ke Kabupaten Magelang.

\section{PENGHARGAAN}

Penelitian ini merupakan penelitian dari dana DIPA Universitas Tidar, maka dari itu Tim penulis berterimakasih kepada LPPM-PMP Universitas Tidar, Rektor Universitas Tidar, dan Dekan Fakultas Ekonomi Universitas Tidar atas bantuan dan dukungannya sehingga penelitian ini dapat terlaksana dan terselesaikan tepat waktu.

\section{DAFTAR PUSTAKA}

Armbrecht, J. (2014). Use value of cultural experiences: A comparison of contingent valuation and travel cost. Tourism Management, 42, 141-148. https://doi.org/10.1016/j.tourman.2013.11.010

Aryanto, R., \& Mardjuka, M. Y. (2005). Valuasi Ekonomi dengan Travel Cost Method pada Obyek Ekowisata Pesisir (Kasus kawasan Ujung Genteng, Sukabumi). Jurnal Imiah Parawisata, 10(1), 58-76. Retrieved from 
https://core.ac.uk/download/pdf/16666224. pdf

Cho, S. H., Bowker, J. M., English, D. B. K., Roberts, R. K., \& Kim, T. (2014). Effects of travel cost and participation in recreational activities on national forest visits. Forest Policy and Economics, 40, 21-30. https://doi. org/10.1016/j.forpol.2013.12.004

Gewati, M. (2019). BI: Industri Pariwisata Jadi Sektor Paling Hasilkan Devisa. Retrieved September 10, 2019, from https://travel. kompas.com/read/2019/03/23/084500627/ bi--industri-pariwisata-jadi-sektor-palinghasilkan-devisa.

Grilli, G., Landgraf, G., Curtis, J., \& Hynes, S. (2018). A travel cost evaluation of the benefits of two destination salmon rivers in Ireland. Journal of Outdoor Recreation and Tourism, 23(February), 1-7. https://doi.org/10.1016/j. jort.2018.02.004

Hadji, K., Wahyudi, M., \& Budi, A. (2017). Potensi dan Pengembangan Wahana Obyek Wisata Alam sebagai Daya Tarik Wisata Edukasi Keluarga di Kabupaten Magelang. The $6^{\text {th }}$ University Research Colloquium 2017 Universitas Muhammadiyah Magelang Potensi, 231-236.

Jala, \& Nandagiri, L. (2015). Evaluation of Economic Value of Pilikula Lake Using Travel Cost and Contingent Valuation Methods. Aquatic Procedia, 4(Icwrcoe), 1315-1321. https://doi.org/10.1016/j.aqpro.2015.02.171

Juliprijanto, W. (2014). Analisis Potensi Sektor Pariwisata di Kabupaten Magelang. Jurnal Penelitian Inovasi, 40(2), 70-85.

Mayer, M., \& Woltering, M. (2018). Assessing and valuing the recreational ecosystem services of Germany's national parks using travel cost models. Ecosystem Services, 31, 371-386. https://doi.org/10.1016/j.ecoser.2017.12.009

Pramudhito, A. (2010). Aplikasi Biaya Perjalanan (Travel Cost) Pada Wisata Alam Studi Kasus: Air Terjun Jumog Kabupaten Karanganyar. Fakultas Ekonomi Universitas Sebelas Maret Surakarta. Universitas Sebelas Maret Surakarta.

Prayaga, P. (2017). Estimating the value of beach recreation for locals in the Great Barrier Reef Marine Park, Australia. Economic Analysis and Policy, 53, 9-18. https://doi.org/http:// dx.doi.org/10.1016/j.eap.2016.10.001

Rahman, M. B., \& Widodo, E. (2018). Perbandingan Metode Regresi Robust Estimasi Least Trimmed Square, Estimasi Scale, dan Estimasi Method Of Moment. Prosiding Seminar Nasional Matematika, 1, 426-433.

Subardin, M., \& M. Komri Yusuf. (2011). Valuasi Ekonomi Menggunaka Metode Travel Cost Pada Taman Wisata Alam Punti Kayu Palembang. Jurnal Ekonomi Pembangunan, 9 (2), 81-89.

Sudarmanto, R. G. (2011). Penentuan Besarnya Sampel Penelitian Menggunakan Rumus Cochran. Retrieved November 7, 2019, from http://staff.unila.ac.id/radengunawan/ files/2011/08/Penentuan-Besarnya-SampelMenggunakan-Rumus-Cochran.pdf

Susilowati, I., Syah, A. F., Suharno, \& Aminata, J. (2018). Economic Valuation of Tourism Attraction of Jatijajar Cave in Kebumen Regency. JEJAK: Jurnal Ekonomi Dan Kebijakan, 11(1), 12-28. https://doi. org/10.15294/jejak.v11i1.13523

Zaman, K., Moemen, M. A., \& Islam, T. (2016). Dynamic Linkages Between Tourism Transportation Expenditures, Carbon Dioxide Emission, Energy Consumption and Growth Factors: Evidence From the Transition Economies. Current Issues in Tourism, 3500 (March), 1-16. https://doi.org/10.1080/1368 3500.2015.1135107

Zambrano-Monserrate, M. A., Silva-Zambrano, C. A., \& Ruano, M. A. (2018). The economic value of natural protected areas in Ecuador: A case of Villamil Beach National Recreation Area. Ocean and Coastal Management, 157 (March), 193-202. https://doi.org/10.1016/j. ocecoaman.2018.02.020 